\title{
Penggunaan Pidana Denda dalam Perundang- undangan
}

\author{
Syaiful Bakhri
}

\begin{abstract}
The application of fine on the national criminal law perspective have got significant progress. It is indicated by the acceptance of philosophy of conmdemnation about fine and a progress from the way of realization for its, conmdemnation by using the various kinds of models introduced, but the glow of this application for fine have not been satisfied entirely, because the trend is that sentence law for criminal is still applied sentence law as a common law. That is why, it need to launch the new thoughts as the breakthrough in order that the functionalization of concept of fine is acceptable as the preventive altematives for crime prospectively.
\end{abstract}

\section{Pendahuluan}

Pidana denda adalah jenis pemidanaan yang telah dikenal secara luas di dunia, dan bahkan di Indonesia: Pidana ini diketahui sejak zaman majapahit dikenal sebagai pidana ganti kerugian. Di Eropa pidana denda adalah pidana yang tertua, dan berlangsung sedemikian lama. Pengkajian pidana denda semakin menarik karena kecenderungan masa kini, banyak negara yang meletakkan sistem pidana dalam bagian terpenting dari kitab Undang-undang Hukum pidananya, bahkan menjadi ukuran dari peradaban. JE. Lakollo menyatakan bahwa semakin banyak dipergunakannya pidana denda dewasa ini sebagai tanda bahwa pidana

denda memberikan warna kultur politik dan kekuasaan. ${ }^{1}$

Pelaksanaan suatu sanksi pidana, dapat dilihat dari suatu proses dalam perwujudan kebijakan melalui tiga tahap, ${ }^{2}$ yakni tahap - penetapan pidana oleh pembuat Undangundang, pemberian atau penjatuhan pidana oleh pengadilan, dan pelaksanaan pidana oleh pihak eksekusi. Tahap kebijakan legislatif adalah suatu proses yang amat penting dan strategis, oleh karena pada tahap ini, sesungguhnya dapat dilihat suatu garis, pedoman untuk tahap-tahap berikutnya, bagaimana pengaruh legislatif terhadap penggunaan pidana, khususnya him 5.

'JE Lakollo, "Perkembangan pidana denda di Indonesia", disertai Doktor di FH. Unair, Sụrabaya, 1998,

${ }^{2} \mathrm{G}$. Peter Hofnagel, The otherside of Criminology (Kluwer Deventer holland, 1969), hlm 138. 
pidana denda dalam perundang-undangan, yang bertujuan untuk menentukan atau merencanakan kebijakan untuk membuatkan sistem yang diatur. ${ }^{3}$

Kajian hukum pidana di bidang legilatif, adalah suatu pembahasan yang penting, oleh karena menentukan suatu landasan legalitas yang diperlukan dalam penerapan dan pelaksanaan pidana. Kebijakan legislatif di bidang pidana denda, sering dihubungkan dengan efektivitas pidana denda, kemudian dijadikan sebagai alternatif dari pidana lainnyạ terutama pidana pencabutan kemerdekaan. Dalam statistik peradilan di Indonesia, diketahui bahwa pidana denda adalah jenis pemidanaan yang paling sedikit digunakan dalam putusan peradilan baik di tingkat pusat maupun di tingkat daerah melalui peraturan daerah (Perda).

Hal demikian dapat dilihat secara signifikan maraknya penggunaan ketentuan pidana dalam perundang-undangan, dan menjadikan pidana denda yang tinggi.disepadankan dengan pidana penjara atau kurungan. Fenomena itu, seyogyanya dapat didentifikasi dari sejumlah motivasi dari pembuat undang-undang, dan beberapa alasan yang melatarbelakangi. Mengapa menggunakan pidana denda, baik secara tunggal alternatif maupun kumulatif dengan pidana penjara. Kemudian landasan atau rumusan apa yang digunakan dalam menentukan besamya denda yang diancamkan pada suatu delik tertentu, dalam perundangundangan itu.

\section{Pidana Denda dan Tujuan Pemidanaan}

Dalam hukum pidana, pencapaian tujuan pemidanaan, hingga sekarang mengalami perdebatan. Hal demikian terjadi karena untuk mepertajam pandangan baik secara filosofis, sosiologis, maupun yuridis pada akhirnya merupakan landasan bagi penerapan sanksi pidana termasuk pidana denda. Perkembangan pemikiran tentang falsafat pemidanaan selain dipengaruhi oleh wama-wami pemikiran sarjana barat, tentu juga dipengaruhi oleh serangkaian politik kriminal, yaitu sebagai keseluruhan asas dan metode yang menjadi dasar dari reaksi terhadap pelanggaran hukum pidana, dan sebagai keselüruhan fungsi dari aparatur penegak hukum dan juga dapat dipandang sebagai keseluruhan dari kebijakan. ${ }^{4}$

Berbagai teori tujuan pemidanaan di masa lalu hingga kini berkembang ke.arah yang rasional. Dimulai dengan teori pembalasan, yaitu bertujuan untuk memuaskan pihak yang dendam, baik masyarakat maupun pihak lainnya. Teori ini menurut Andi Hamzah adalah sangat bersifat primitif, akan tetapi diakuinya, bahwa kadang-kadang masih dirasakan pengaruhnya pada zaman modern, karena unsur primitif dalam hukum pidana paling sukar untuk dihilangkan. Berbeda dengan cabang hukum lainnya, tujuan yang dipandang kuno, yakni penghapusan dosa (expiation) atau retribusi (retribution). ${ }^{5}$ Teori pembalasan

${ }^{3}$ Roeslan Saleh, "Melihat Kebelakang dan Menatap Kedepan Dengan Memperkokoh Dasar Hukum Yang Berlaku Hingga Kini Dan Diwaktu Akan Datang", Seminar Kepolisian RI (Jakarta, 1996), hlm 34.

4 Sudarto, Hukum Pidana dan Perkembagan Masyarakat: Kajian Terhadap Hukum Pidana, (Bandung: Sinar Baru, Tanpa Tahun), him 113-115.

${ }^{5}$ Andi Hamzah, Sistem Pidana dan Pemidanaan Indonesia, dari Retribusi ke Reformasi (Jakarta: Pradnya Paramita, 1985), hlm 16. 
menurut Leo Polak dibagi dalam berbagai variasi, yakni: (1) Pertahanan kekuasaan hukum atau pertahanan kekuasaan negara, yakni pidana merupakan paksaan belaka, dan putusan pidana adalah sebagai penderitaan; (2) Teori Kompensasi, yakni bila pembalasan tidak dibalas maka timbullah perasaan tidak puas. Memidana penjahat adalah suatu keharusan estetika. Teori ini melenyapkan segala sesuatu yang menjadi akibat dari suatu perbuatan yang bertentangan dengan hukum dan penghinaan. Etika tidak dapat mengijinkan berlakunya suatu kehendak subjektif yang bertentangan dengan hukum yang sama terhadap setiap anggota. (3) Teori pembalasan, dalam menyelenggarakan persamaan hukum. Ménurut teori ini bahwa asas persamaan hukum yang berlaku bagi semua anggota masyarakat menuntut suatu perlakuan menurut suatu hukum yang sama terhadap setiap anggota. Teori untuk melawan kecenderungan untuk memuaskan keinginan yang bertentangan dengan kesusilaan. Bahwa diperlukan untuk membalas, tidak ditujukan kepada persoalan apakah orang lain akan mendapat bahagia atau menderita, tetapi keperluan untuk membalas itu ditujukan kepada niat masingmasing orang. Segala yang bertentangan dengan kesusilaan, tidak boleh didapatkan orang. ${ }^{6}$

Sehubungandengan itu, Kantmengemukakan bahwa perbuatan melanggar hukum yang telah terjadi itu mendapat pembalasan, dan hukum merupakan suatu keharusan yang tidak menghendaki pengecualian. Hegel mengatakan perbuatan melanggar hukum merupakan perbuatan yang tidak manusiawi, dan hukum adalah pembalasan, pelakunya dihargai sebagai pribadi berat ringannya hukuman tergantung kesalahannya. Stahi menyatakan bahwa asas pembalasan bersumber pada ketuhanan dan itu merupakan Undang-undang yang bersifat abadi. Kejahatan harus dibalas oleh negara, terhadap pembalasan itu negara harus menderitakan pelakunya. Von Bar, dalam hal pemidanaan mengemukakan bahwa hukum harus mendapatkan sifat kesusilaan yang dikehendaki oleh moral akan tetapi dengan peradaban yang semakin maju, maka bentukbentuknya harus semakin halus.?

Tujuan dari teori pemidanaan adalah untuk mencari dasar dari hukum pidana dalam menyeleggarakan tertib masyarakat dan akibatnya tujuan pidana untuk prefensi terjadinya kejahatan, dengan menakut-nakuti, memperbaiki, selanjutnya dibedakan menjadi prefensi umum dan prefensi khusus. Dalam usaha untuk mencari berbagai alternatif dari berbagai pemidanaan yang berkembang dan tersebar dalam ilmu pengetahuan hukum pidana, maka teori-teori dan model yang ditawarkan, tentu tidak boleh hanya memilih salah satu dari model pemidanaan yang menjadi sorotan tertentu saja.

Sehubungan dengan itu, perlu dilkuti teori pemidanaan dari Herbert $L$. Packer, yaitu pandangan retributif, yang mengajukan bahwa pidana adalah suatu ganjaran terhadap suatu perilaku yang menyimpang dalam masyarakat. Pandangan Utilitarian melihat bahwa pidana itu

\footnotetext{
${ }^{6} /$ bid., hlm 17.

'Simons, Kitab Pelajaran Hukum Pidana, terjemahan oleh PAF Lamintang (Bandung: Pioner Jaya, 1981),
7-8.
} 
dilakukan dilihat dari aspek manfaat dan kegunaannya. Pandangan retributif mengemukakan pada pilihan moral, maka ganjarannya adalah positif dan mendapat penighargaan dari masyarakat, akan tetapi bila salah maka patut dijatuhkan sebagai ganjaran yang merupakan suatu ganjaran atau sanksi negatif. Dalam pandangan Utilitarian, penjatuhan pidana harus dilihat dari aspek tujuan, manfaat dan kegunaan, untuk perbaikan dan pencegahan pandangan itu bersifat pencegahan atau prefentif. Menurutnya pemidanaan adalah suatu tindakan yang menyebabkan derita bagi terpidana, bila temyata memang telah terbukti bahwa kejahatan itu menimbulkan akibat lebih baik dari pada tidak dijatuhkan pidana, atau dengan penggunaan detterence yang dibaginya menjadi dua, ${ }^{8}$ yakni: Pertama, detterence theory, dimana efek-efek pencegahannya timbul sebelum pemidanaan dilakukan, kemudian teori ini dibagi menjadi: a). special Detterence, dimana pidana yang dijatuhkan terjadi setelah pemidanaan dilakukan (penjeraan); b).General dettrence, yakni pidana yang dijatuhkan diharapkan terjadi sebelum pemidanaan dilakukan. Kedua, intimidation theory, yang memandang bahwa. pemidanaan merupakan sarana untuk mengintimidasi mental terpidana.

Pandangan yang lain dari pencegahan (preventif) di mana pangkal.tolaknya adalah tingkah laku pelaku pidana itu. Pandangan (bahavioral Prevention) ini meliputi teoriteorinya; a). incapacition theory, yakni pada pidana penyekapan, adalah dilihat sebagai sesuatu yang harus dilakukan, supaya terpidana tidak lagi dapat melakukan perbuatan anti sosial;' b). Rehabilitation theory, bahwa pemidanaan dilakukan untuk memudahkan dilakukan pembinaan terhadap terpidana.

Dari pemikiran ahli hukum pidana di Indonesia, dapat dilihat berbagai tujuan pemidanaan. Menurut J.E. Sahetapy, tujuan pidana adalah pembebasan atau pemasyarakatan dan pembinaan, yang pada akhimya menuju pada kemanusiaan yang adil. dan beradab sebagaimana tersurat dan tersirat dalam asas Pancasila. ${ }^{9}$ Muladi mengemukakan teori pemidanaan yang terintegratif, (kemanusiaan dalam pancasila). ${ }^{10}$ Sehubungan dengan itu Barda Nawawi Arief mengemukakan bahwa tujuan pemidanaan adalah perlindungan masyarakat yang merupakan tujuan yang umum dan bersifat khusus dengan berinduk pada semua teori tentang tujuan pemidanaan yang saling berhubungan merincikan dan mengindentifikasikan dari tujuan umum itu."

Pada Rancangan KUHP dikenal sitem pemidanan yang berpedoman pada: 1). Mempergunakan ancaman pidana mati secara efektif dan karena itu mencatumkan pidana mati sebagai pidana khusus; 2). Lebih banyak

${ }^{8}$ Herbert L Packer, "Limit of Criminal Sanction...," oleh Marjono Reksodiputro dan Sri Budiarti, Bahan Kuliah Sistem Peradilan Pidana, Jilid I, (Jakarta: Pusat Dokumentasi Hukum Ul, 1983), hlm 3-8.

- J.E Sahetapy, Suatu Studi Khusus Mengenai Ancaman Pidana Mati terhadap Pembunuhan Berencana (Jakarta: Rajawali, 1982), hIm 249.

${ }^{10}$ Muladi, Lembaga Pidana Bersyarat, (Bandung: Alumni, 1985), hlm 50.

"Barda Nawawi Arief, "Kebijakan Legislatif Mengenai Penetapan Pidana Penjara dalam Rangka Usaha Penanggulangan Kejahatan", disertasi Doktor di UNPAD-Bandung, 1985, hlm 153-168. 
menggunakan ancaman pidana denda dan untuk memudahkan perobahan nilai denda karena inflasi maka dipergunakan sistem kategorisasi denda itu dan membatasi penggunaan ancaman pidana penjara jangka pendek, dengan mengganti pidana penjara di bawah satu tahun dengan ancaman pidana denda. ${ }^{12}$

Masalah tujuan pemidanaan dalam pidana, tidak dapat dipisahkan dari kebijakan kriminal dalam menggunakan hukum pidana, yang meliputi perbuatan apa yang seharusnya dijadikan tindak pidana dan sanksi apa yang sebaiknya digunakan atau dikenakan kepada pelaku delik.

Masalah perbuatan apa yang seharusnya dijadikan tindak pidana (kriminologi) Sudarto mengemukakan: a). Penggunaan hukum pidana harus memperhatikan tujuan pembangunan nasional, yaitu masyarakat adil, makmur berdasarkan Pancasila, dan penggunaan hukum pidana bertujuan untuk menanggulangi kejahatan dan mengadakan pengugeran terhadap tindakan penaggulangan itu sendini, demi kesejahteraan dan penganyoman masyarakat, b). Perbuatan yang diusahakan untuk dicegah dan ditanggulangi dengan hukum pidana harus merupakan perbuatan yang tidak dikehendaki yaitu, perbuatan yang mendatangkan kerugian atas warga masyarakat, c). Penggunaan hukum pidana harus pula mempertitungkan prinsip biaya dan hasil (cost benefit principle), dan d) Penggunaan hukum pidana harus pula memperhatikan kapasitas atau kemampuan daya kerja dari badan-badan penegak hukum yaitu jangan sampai ada kelampauan beban tugas (overblasting). Dalam hal pidana denda, bila dihubungkan dengan tujuan-tujuan pemidanaan, maka akan nampak bahwa hubungan itu terletak pada kejahatan-kejahatan terhadap hàrta benda. Oleh karena itu dalam hal pelaksanaan pidana tidak boleh melebihi keadaan-keadaan yang secara limitatif dilarang oleh sanksi-sanksi tertentu. Oleh karena itu harus dicari keserasian antara kerugian yang timbul oleh suatu tindak pidana dengan besarnya pidana denda yang harus dibayar oleh terpidana, karena itu harus dipertimbangkan dengan seksama minimum maupun maksimum pidana yang diancamkan terhadap suatu tindak pidana. ${ }^{13}$

Bila tujuan telah menemukan keserasian, keharmonisan dari kerugian yang ditimbulkan oleh tindak pidana, dengan besamya yang mesti dibayar, maka pemidanaan itu meliputi tahaptahap perumusan ancaman pidana oleh pembuat undang-undang, dan tahap pelaksana penegakan di pengadilan dan suatu tahap pelaksanaan oleh penegak hukum lainnya, yang tentunya diberikan wewenang oleh pembuat undang-undang. Sehubungan dengan itu dan dalam rangka untuk memperluas penggunaan pidana denda dan meningkatkan jumlah ancaman pidana denda saja ternyata belum mencukupi untuk menigkatkan efektivitas pidana denda. Untuk itu diperlukan suatu kebijaksanaan yang menyeluruh dalam bidang legislatif, yudikatif, maupun eksekutif. Dalam hal ini, Muladi dan Barda Nawawi Ariefismengemukakan bahwa dalam pelaksanaan pidana denda perlu dipertim-

${ }^{12}$ Mardjono Reksodiputro, Pembaharuan Hukum Pidana, Buku ke-4 (Jakarta: Pusat Pelayanan Keadilan dan Pengabdian Hukum dan Lembaga Kriminologi, Ul-Jakarta, 1995), hlm 2-6.

${ }^{13}$ Lihat Sudarto, Hukum dan Hukum Pidana, 1997, him 44-48.

${ }^{14}$ Muladi dan Barda Nawawi Arief, Teori-Teoridan Kebijakan Pidana (Bandung, Alumni, 1992), hlm.177. 
bangkan antara lain: Sistem penetapan jumlah atau besarnya pidana denda; Batas waktu pelaksanaan pidana denda; Tindak-tindakan paksa, yang diharapkan dapat menjamin terlaksananya pembayaran denda dalam hal terpidana tidak membayar dalam batas waktu yang ditetapkan; Pelaksanan pidana denda dalam hal-hal khusus (misalnya terhadap anak yang belum dewasa atau belum bekerja merupakan tanggungan orang tuanya); dan pedoman atau kriteria untuk menjatuhkan pidana denda.

Sehubungan dengan manfaat, keuntungan, dan rasa keadilan tentang penerapan pidana denda dapat diikuti pandangan Sutherland dan Cressey ${ }_{15}^{15}$ yakni, pembayaran denda mudah dilaksanakan dan dapat direvisi apabila ada kesalahan, dipandang dengan jenis hukuman lainnya. Pidana denda adalah jenis hukuman yang menguntungkan pemerintah, karena pemerintah tidak banyak mengeluarkan biaya, bila tanpa disetai dengan kerugian subsidair. Hukuman denda tidak membawa atau tidak menigakibatkan tercelanya nama baik atau kehormatan seperti yang dialami terpidana. Pidana denda akan membuat lega dunia perikemanusiaan. Hukuman denda akan menjadi penighasilan bagi daerah/kota.

\section{Pidana Denda dalam Perundang- undangan}

Berbagai dampak negatif yang dihasilkan oleh pidana penjara, telah membawa pengaruh untuk terjadinya altematif pengganti pidana penjara, walaupun di sana sini masih diperdebatkan juga tentang masih perlunya pidana penjara. Akibat dari pidana penjara, bila dihitun'g dari biaya yang mesti dikeluarkan \{social cost\} begitu besar. Oleh karenanya pengurangan biaya sosial, dapat dicapai ataupun diperoleh dengan penggunaan pidana denda. Diketahui pula bahwa, pidana denda juga telah memenuhi tujuan pemidanaan, selain itu pidana denda telah mendunia dan menjadi pidana primadona dan dikenal dalam rentang sejarahnya di masa depan. Pidana denda merupakan suatu sarana yang efektif dan mempunyai dampak yang lebih baik bila dibandingkan dengan pidana penjara. Suatu kecenderungan penggunaan pidana di dalam perundang-undangan, baik di tingkat pusat, maupun daerah, adalah agar Undang-undang yang dibuat, diharapkan dapat ditegakkan, untuk menjaga supaya norma-norma yang diatur oleh pembuatnya dapat ditaati.

Aktivitas pembuat undang-undang adalah menetapkan peraturan-peraturan yang sebenarnya telah hidup di dalam masyarakat. Dalam perkembangan selanjutnya tugas pembuat undang-undang adalah untuk mengadakan, mengarahkan serta mendorong perubahan dalam masyarakat, serta memberi sumbangan terhadap pembentukan perubahan masyarakat, sehingga pembentuk Undangundang harus mendahului perubahan masyarakat.

Bilamana Undang-undang digunakan sebagai sarana perubahan, maka perundangundangan akan merupakan bagian dari kebijaksanaan sosial, ekonomi, kebudayaan, piskal, moneter dan sebagainya. Dengan

${ }^{15}$ Sutherland \& Cressey, "The Control Crime," Hukum dalam Perkembangan Hukum Pidana, disadur oleh Sudjono D (Bandung: 1974), hIm 487 
demikian, maka undang-undang adalah rangkaian dari alat pemerintah untuk mewujudkan kebijakannya. Menurut Roeslan Saleh para ahli hukum, masih sedikit sekali perhatiannya terhadap aspek perundangundangan yang terintegrasi dalam suatu rangkaian sarana-sarana kebijaksanaan. ${ }^{16}$

Dalam pertumbuhannya bahwa Undangundang adalah untuk melaksanakan, menentukan, merencanakan kebijaksanaan itu, semakin banyak memakai sanksi pidana dan. merupakan bagian penutup dari rangkaiàn aturan kebijaksanaan itu. Sanksi pidana diperlukan untuk menyelesaikan dan membulatkan sistem yang diatur, dan merupakan komplemen yang tidak digunakan dari pemberian wewenang kepada pemerintah. Dalam rangka itu pemerintah dan pembuat Undang-undang akan merubah watak masyarakat, perundang-undangan hanya untuk memperkuat atau untuk memberikan kekuasaan kepada pemerintah, dan pembentuk undangundang cenderung untuk melimpahkan halhal yang sifatnya terinci kepada pemerintah. ${ }^{17}$ Negara hukum - Indonesia dalam perkembangannya diakhir abad 20 , telah sempuma menjadi government social control dan bertungsi sebagai tool of social engineering. Hukum dan perundang-undangan telah menjadikan kekuatan kontrol di tangan pemerintah yang terlegitimasi secara formal yuridis, dan tidak selamanya merefleksikan konsep keadilan, asasasas moral, wawasan kearifan. ${ }^{18}$ IImu hukum telah terlalu kuat mengkonsentrasikan diri pada produk perundang-undangan dan peradilan, sehingga ilmu hukum menjadi ilmu yang berhubungan dengan peradilan. ${ }^{19}$

Perundang-undangan yang menentukan ketentuan pidana, terutama pidana denda, telah menyemarakan dan menjadikan pidana denda menjadi pidana yang modern dan aktual. Dengan pidana denda yang tinggi sebagaimana direfleksikan dalam undang-undang administratif, pembuat undang-undang ingin menjaga undang-undang yang dibuatnya melalui pidana denda yang tinggi. Agar undang-undang itu dipatuhi serta menjaga pula akibat-akibat dari dilarangnya norma perundang-undangan itu.

Akan tetapi dilihat dari perspektif hukum pidana, terdapat suatu kekurangan pada penerapan penegakan hukumnya, oleh karena pada ketentuan pidana, di mana pemidanaannya terjadi suatu akumulasi pidana penjara dan denda, tidak menentukan atau merumuskan minimum khusus. Misalnya pada undangundang Nomor 22 Tahun 2002 tentang Migas, di mana ketentuan pidana denda setinggitingginya Rp 60 Milyar, tidak dilikutidengan pidana denda minimumnya, sehingga perilaku atau hakim akan memainkan peranannya secara normatif. Dengan bergerak bebas di antara maksimum hukuman sebagaimana ditentukan dalam Undang-undang ,atau minimum 1 hari pidana penjara atau minimum Rp 250,- (dua ratus lima puluh rupiah) untuk pidana denda. hal demikian merupakan suatu kekurangan dảam perumusan ketentuan pidana. Akan

${ }^{16}$ Roeslan Saleh, op.cit., hlm 34-35.

${ }^{17}$ Ibid., hIm 35.

${ }^{18}$ Soetandyo Wingjosoebroto, Dari Hukum Kolonial ke Hukum Nasional, (Jakarta: PT. Raja Grafindo Persada, 1995), hlm 247.

${ }^{19}$ A. Hamid. SAttamimi, "Teori Perundang-undangan indonesia," pidato pengukuhan Guru Besar di FH Ul, Depok, 1992, hlm 5. 
tetapi menurut Roeslan Saleh, bahwa hakim kerapkali akan melihat hasil perundangundangan dari segi lain, guna melindungi warga negara dari tindakan pemerintah terutama dalam masyarakat yang sangat birokratis. ${ }^{20}$

Dalam perkembangan dipakainya pidana denda dalam perundang-undangan, belum diketahui secara pasti, ukuran-ukuran yang jelas kesepadaan antara pidana penjara dengan denda. Juga jumlah pidana yang tinggi disepadankan dengan bahaya atau larangan dari norma yang akan ditentukan larangannya. Sehubungan dalam masalah ini, Roeslan Saleh mengemukakan adanya dua unsur pembiayaan pemidanaan, yaitu: Pertama, kemungkinan pemidanaan; dan Kedua, biaya pidana dari pelaku perbuatan kriminal itu jika memang terlaksana. Bahwa tugas pertama dalam menyusun skema pemidanaan suatu perbuatan kriminal tertentu adalah memilih pembiayaan pemidanaan yang diperkirakan. Hal ini setidaknya sebanding dengan kerugian yang diderita oleh korban perbuatan kriminal itu. Selanjutnya harus dipertimbangkan pada pelaku bahwa kriminal dapat dihitung jika keuntungan yang diperkirakannya untuk dirinya sendiri melebihi, "social cost". Begitu pula sanksi haruslah sepadan bila pelaku melakukan kegiatan yang dilarang oleh peraturan perundangundangan. Sebagai gambaran, seandainya pencuri telah melakukan perbuatannya di mana kemungkinan pencuri itu akan ditangkap dan dipidanà, maka pidananya itu harus sebanding dengan biaya kerugian pada korban karena pencurian. Selanjutnya bila pencuri terhalang melakukan pencuriannya disebabkan menurut perhitungannya, benda yang dicurinya itu harganya kurang dari biaya yang sebenamya. Dengan mendorong pencuri tidak melakukan, maka harus diatur biaya pidana yang diperkirakan itu adalah lebih besar dari pada social cost dari benda yang dicuri. Contoh lain adalah pengemudi yang melanggar kecepatan mengemudi, karena opportunity cost dengan waktunya àdalah sangat tinggi, maka dendanya akan merefleksikan bahaya mengemudinya itu. ${ }^{21}$

Oleh karena pidana denda dan pidana penjara dibedakan semata-mata karena berbeda pula mengenai beban-beban pembiayaan ekonomis, pada pelakụ kriminil, sebenarnya tidak tepat apabila terkesan bahwa putusan dengan pidana denda dapat menjadi pidana penjara, jika terpidana tidak dapat atau tidak bersedia untuk membayar dendanya. $\mathrm{Hal}$ ini akan menjadi diskriminatif terhadap terpidana yang miskin jika pidana itu dapat diganti. Oleh sebab itu mengenai nilai tukar itu harus realistis dan tidak hanya menguntungkan satu pihak saja. Hukum pidana denda adalah salah satu dari jenis pidana pokok dalam stelsel pidana pada umumnya. Apabila objek dari pidana penjara ialah kurungan sedangkan objek dari pidana denda adalah harta benda dari pembuat delik. Harta benda yang dimaksudkan adalah berupa uang, bukan dalam bentuk natural baik yang bergerak maupun yang tidak bergerak.

Penerapan pidaña denda di Indonesia dengan perkembangan globalisasi dan penganuh para ahil hukum pidana akan menampakkan masa kecerahan di masa depan. Kecenderungan

\footnotetext{
${ }^{20}$ Roeslan Saleh, op.cit., him 33

${ }^{21}$ Roeslan Saleh, Hukum Pidana dilihat dari Ekonomi Hukum, (1995), him 4-5
} 
itu terbukti dengan maraknya penggunaan pidana denda yang tinggi dalam perundang-undangan yang memuat ketentuan pidana serta perkembangan rancangan KUHP yang memakai katagorisasi denda dan dikenalnya pula sistem eksekusi pidana denda dengan model denda-harian (day fine).

Pada rancangan KUH Pidana mendatang merumuskan tentang bentuk rumusan delik yang dapat diidentifikasi sebagai berikut: KUHP hanya menganut sistem perumusan tunggal dan alternatif. Pidana pokok dirumuskan secara tunggal, pidana tambahan bersifat fakultatif. Namun pada dasarnya untuk dapat dijatuhkan harus tercantum dalam perumusan delik. Sebagai perbandingan di negeri Belanda, populasi penjara sangat kecil olẹ karena adanya sistem penyelesaian perkara tertentu di luar pengadilan, dan penerapan yang luas dari pidana denda. ${ }^{22}$ Di Inggris, sejak 1948, hampir semua pidana diselesaikan dengan denda. Hal itu diakibatkan oleh terjadinya perkembangan pandangan dibidang politik kriminal yang mempengaruhi perkembangan hukum pidana. Di Jerman dan Austria, bentuk pidana perampasan kemerdekaan dialternatifkan sebagai pengganti penjara dan diperlakukan apa yang dikenal dengan denda harian (day fine). Di Cina mengenal juga pidana denda. dan jumlah dendanya disesuaikan dengan keadaan-keadaan waktu kejahatan dilakukan. Jika pelaku tidak dapat membayar atau tidak mampu maka dendanya dapat dikurangi atau dihapuskan.

\section{Simpulan}

Hukum pidana, merupakan suatu upaya akhir dari upaya hukum lainnya, karena sifat hukum pidana yang memberikan nestapa dan sekaligus membuat jera pada pelaku delik. Pelaksanaan pidana pada masa lalu dititik beratkan pada pidana penjara (kurungan). Akibat pidana ini, memberikan dampak yang negatif. Dari beberapa penelitian menyimpulkan bahwa pidana penjara memberikan kontaminasi dari budaya yang buruk, sehingga terpidana berkecenderunganmengikuti budaya itu.

Pidana denda, sebagai pidana nestapa terhadap harta benda bagi pembuat delik, merupakan solusi untuk menggantikan pidana badan, dalam hal ini telah menjadi bukti atas keberhasilan di negara-negara lain, bahkan pidana denda dapat pula mendorong terciptanya ketertiban hukum dan sekaligus meningkatkan kewibawaan hukum.

Di negara Eropa berkacenderungan penentuan pidana denda ini semakin kuat, hal itupun diikuti negara Asia. Bahkan Indonesia yang telah menyelesaikan rancangan KUHP Pidana baru, mencantumkan penentuan pidana denda baik sebagai pidana tunggal maupun alternatif dari pidana lainnya.

Demikian pula dampak pada perundangundangan di mana hampir setiap undangundang memuat ketentuan pidana, khususnya denda, sehingga pidana denda dapat diterima dalam perkembangan hukum modem.

${ }^{22}$ Andi Hamzah, op.cit., hlm 10 


\section{Daftar Pustaka}

Arief , Barda Nawawi. "Kebijakan Legislatif Mengenai Penetapan Pidana Penjara dalam Rangka Usaha Penanggulangan Kejahatan," disertasi doktor di UNPADBandung: 1985.

Attamimi , A. Hamid S. "Teori Perundangundangan Indonesia", pidato pengukuhan Guru Besar di FH UI, Depok, 1992.

Hofnagel G. Peter. The otherside of Criminology, Kluwer Deventer holland, 1969.

Hamzah, Andi. Sisten Pidana dan Pemidanaan Indonesia, dari Retribusi ke Reformasi, Jakarta, Pradnya Paramita, 1985.

Lakollo, JE. "Perkembangan pidana denda di Indonesia," Disertai Doktor di FH. Unair, Surabaya, 1998.

Muladi dan Barda Nawawi Arief. Teori-Teori dan Kebijakan Pidana, Bandung: Alumni, 1992.

Muladi. Lembaga Pidana Bersyarat, Bandung: Alumni, 1985.

Packer, Herbert L. Limit of Criminal Sanction..., oleh Marjono Reksodiputro dan Sri Budiarti, Bahan Kuliah Sistem Peradilan Pidana, Jilid I, Pusat Dokumentasi Hukum Ul, Jakarta: 1983.

Reksodiputro, Mardjono. Pembaharuan Hukum Pidana, Jakarta: Buku ke-4,
Pusat Pelayanan Keadilan dan Pengabdian Hukum dan Lembaga Kriminologi, Ui-Jakarta, 1995.

Sahetapy, J.E. Suatu Studi Khusus Mengenai Ancaman Pidana Mati terhadap Pembunuhan Berencana, Jakarta: CV. Rajawali, 1982.

Saleh, Roeslan. Hukum Pidanà dilihat dari Ekonomi Hukum., 1995. , "Melihat Kebelakang dan Menatap. Kedepan Dengan Memperkokoh Dasar Hukum Yang Berlaku Hingga Kini Dan Diwaktu Akan Datang," seminar Kepolisian RI, Jakarta, 1996.

Simons. Kitab Pelajaran Hukum Pidana, terjemahan oleh PAF Lamintang, Bandung: Pioner Jaya, 1981.

Sudarto. Hukum dan Hukum Pidana, 1997. Hukum Pidana dan Perkembangan Masyarakat: Kajian Terhadap Hukum Pidana, Bandung: Sinar Baru, tanpa tahun.

Sutherland \& Cressey. "The Control Crime," Hukum dalam Perkembangan Hukum Pidana, disadur oleh Sudjono D. Bandung: 1974.

Wingjosoebroto, Soetandyo. Dari Hukum Kolonial ke Hukum Nasional, Jakarta: PT. Raja Grafindo Persada, 1995. 